\title{
BOBOT TELUR (BT), HAUGH UNIT (HU), INDEKS KUNING TELUR (IKT), DAN KEKENTALAN TELUR (KT) PADA ITIK MAGELANG DI DUSUN SEMPU, DESA NGADIROJO, KECAMATAN SECANG, KABUPATEN MAGELANG
}

\author{
Egg Weight (EW), Haugh Unit (HU), Egg Yolk Index (EYI), and Egg Consistency (EC) of \\ Magelang Ducks in Sempu Hamlet, Ngadirojo Village, Secang District, Magelang Regency
}

\author{
Ayu Rahayu1, Shinta Ratnawati², Rahma Wulan Idayanti', Budi Santoso', \\ dan Nadia Ade Luthfiana ${ }^{1}$ \\ 1Program Studi Peternakan, Fakultas Pertanian, Universitas Tidar Magelang \\ 2Program Studi Manajemen, Fakultas Ekonomi, Universitas Tidar Magelang \\ Email:ayu.rahayu@untidar.ac.id
}

\begin{abstract}
ABSTRAK
Penelitian tentang kualitas telur itik yang mencakup Indeks Kuning Telur (IKT), Haugh Unit (HU), Bobot Telur (BT) dan Kekentalan Telur (KT) Itik Magelang penting dilakukan untuk mengetahui kemampuan genetik Itik Magelang sebagai upaya untuk menyediakan dan meningkatkan bahan pangan sumber protein hewani yang berkualitas. Penelitian ini bertujuan untuk menganalisis kualitas telur dari Itik Magelang, ditinjau dari nilai IKT, HU, Bobot Telur dan Kekentalan Telur. Penelitian ini dilaksanakan di Dusun Sempu, Desa Ngadirojo, Kecamatan Secang, Kabupaten Magelang. Penelitian dilakukan dengan mengukur kualitas telur dari masing-masing itik yang berada pada fase layer. Sampel telur diambil dari tiga peternak itik yang berbeda dengan total telur sebanyak 100 butir. Data dianalisis menggunakan standar deviasi dengan Microsoft excel. Hasil analisis menunjukkan BT Itik Magelang berada pada kisaran 64,65-66,63 gram/butir. Nilai HU 102,49105,26 dan nilai IKT 0,38-0,44 sedangkan KT menunjukkan hasil yang seragam. Perbedaan setiap analisis kualitas telur dipengaruhi oleh beberapa faktor di antaranya pakan yang diberikan, tempat pemeliharaan, dan lama penyimpanan telur. Semakin lama penyimpanan telur akan berpengaruh terhadap BT, HU, IKT dan KT. Kesimpulan dari penelitian ini adalah antara nilai BT, HU dan IKT menunjukkan hasil yang saling berkaitan.
\end{abstract}

Kata kunci: Berat Telur, Haugh Unit, Indeks Kuning Telur, Itik Magelang, Kekentalan Telur

\begin{abstract}
ABSRACT
The research quality of duck eggs that includes Egg Yolk Index (EYI), Haugh Unit (HU), Egg Weight (EW) and Egg Consistency (EC). Magelang Ducks is important to know the genetic characteristics of Magelang Ducks to provide and improve quality of animal product. The study aim of this research was to analyze the quality of Magelang Ducks eggs, includes the value of IKT, HU, Egg Weight and Egg Viscosity. A total of one hundred Magelang Duck in the layer phase was randomly selected from three duck farmer in Sempu Hamlet, Ngadirojo Village, Secang District, Magelang Regency. The research was conducted by measuring the quality of each ducks eggs. The data were analyzed using a standard deviation analysis using the microsoft excel system. The results showed that the EW Magelang duck was range of 64.65-66.63 gram/egg. HU value was 102.49-105.26 and the EYI value was 0.38-0.44, respectively. In addition, eggs had similar viscosity. Variations among individual eggs were influenced by several factors such as feed, environment and storage time. Time storage affect EW, EC, HU and EYI. The conclusion of the research showed that between EW, HU EYI value showed interconnectedness, while EC showed good uniformity.
\end{abstract}




\section{PENDAHULUAN}

Itik Magelang merupakan salah satu unggas lokal produktif sebagai penghasil telur. Seiring dengan aktivitas domestikasi, Itik melakukan berbagai adaptasi untuk menyesuaikan diri pada lingkungan yang baru. Adaptasi yang dilakukan seperti tingkah laku yang sangat aktif baik di kandang atau di luar kandang (Suryana \& Yasin, 2013). Itik Magelang memiliki ciri khas kalung putih di lehernya, Itik ini beperan sebagai penghasil telur yang berkisar antara 48-70\% per tahun, jika dipelihara secara intensif produksinya bisa mencapai 80\%, Itik Magelang yang afkir dimanfaatkan sebagai itik pedaging (Yuniwarti \& Muliani, 2014). Menurut Isomoyowati \& Purwantini (2013) Itik Magelang memiliki proporsi tubuh yang besar yang dapat mencapai 1,5 kg, produksi telur relatif tinggi dan mempunyai warna bulu bervariasi dibandingkan dengan itik lokal lainnya.

Telur itik merupakan salah satu sumber protein hewani yang memiliki rasa yang lezat, mudah dicerna dan bergizi tinggi. Telur itik umumnya berukuran besar dan warna kerabang putih sampai hijau kebiruan. Rata-rata bobot telur itik adalah 60-75 gram. Keunggulan telur itik dibandingkan dengan telur unggas lainnya antara lain kaya akan mineral, vitamin B6, asam pantotenat, tiamin, vitamin A, vitamin E, niasin dan vitamin B12 (Purdiyanto \& Riyadi, 2018). Kualitas telur dapat diartikan sebagai sekumpulan sifat-sifat yang dimiliki oleh telur dan memiliki pengaruh terhadap penilaian konsumen. Menentukan kualitas telur terutama bagian isi dalam telur dapat diketahui dengan peneropongan dan melakukan penilaian kualitas internal telur dengan memecahkan telur kemudian menempatkannya pada meja kaca, selanjutnya penilaian utama dilakukan terhadap putih dan kuning telur. Penentuan kualitas internal telur yang paling baik adalah berdasarkan HU yang merupakan indeks dari tinggi putih telur kental terhadap berat telur. Semakin tinggi nilai HU, semakin baik kualitas putih telur, ini menandakan telur masih segar. Kualitas kerabang telur meliputi bentuk, kelicinan, ketebalan, keutuhan dan kebersihan (Kurtini, et al., 2011).

Penentuan kualitas telur dapat dilakukan melalui pengukuran terhadap variabel Bobot Telur (BT), Haugh Unit (HU), Indeks Kuning Telur (IKT), dan Kekentalan Telur (KT). IKT dan HU ini sangat dipengaruhi oleh kandungan protein dalam pakan yang diberikan. Menurut Purnamaningsih (2010), semakin tinggi kandungan protein dalam pakan yang diberikan maka nilai IKT akan semakin tinggi, pembentukan protein albumen akan meningkat dan akan meningkatkan nilai HU. Ahmadi \& Rahimi (2011) menyatakan bahwa setiap spesies memiliki kemampuan metabolisme berbeda sehingga produk akhir yang dihasilkan berbeda pula. Penelitian tentang pengaruh lama simpan terhadap kualitas internal telur Itik Magelang yang meliputi Indeks Kuning Telur (IKT), Haugh Unit (HU), bobot dan kekentalan telur pada Itik Magelang di Dusun Sempu, Desa Ngadirojo, Kecamatan Secang, Kabupaten Magelang belum diketahui, oleh sebab itu, penulis tertarik untuk melakukan penelitian ini.

\section{METODE}

Penelitian dilakukan di Dusun Sempu, Desa Ngadirojo, Kecamatan Secang, Kabupaten Magelang dengan melakukan survei ke beberapa peternak yang ada di daerah tersebut. Peralatan yang digunakan untuk penelitian adalah kaca datar dengan ketebalan $3 \mathrm{~mm}$ yang digunakan untuk alas meletakkan telur setelah dipecah untuk kemudian dilakukan pengukuran, jangka sorong untuk mengukur lebar, panjang dan ketinggian/kedalaman telur, timbangan digital dengan ketelitian 0,1 gram untuk mengetahui berat telur, cawan petri untuk meletakkan putih dan kuning telur, tissu untuk membersihkan peralatan yang digunakan, kantung plastik sebagai tempat penampung telur yang sudah dipecah. Bahan yang digunakan adalah alkohol 70\% untuk membersihkan kotoran dari 
cangkang telur dan mensterilkan peralatan yang akan digunakan, serta telur Itik Magelang dengan masa simpan 2-5 hari.

\section{Parameter yang diamati}

Parameter yang diamati adalah indeks kuning telur, nilai haugh unit, bobot telur, diameter kuning telur, tinggi kuning telur, tinggi albumen dan kekentalan telur. Prosedur penghitungan IKT dan HU merupakan hasil dari pengukuran bobot telur, diameter kuning telur, tinggi kuning telur dan tinggi albumen.

a. Perhitungan Haugh Unit (HU)

\section{Analisis Statistik}

Perhitungan HU merupakan pengukuran tinggi albumen dan bobot telur. Telur yang sudah ditimbang menggunakan timbangan digital dipecah, pecahan telur tersebut diletakkan di atas kaca datar kemudian ketinggian albumen diukur menggunakan jangka sorong. Panda (1996) menyatakan rumus haugh unit yang dibuat oleh Raymond Haugh yaitu:

$\mathrm{HU}=100 \log \left(\mathrm{H}+7,57-1,7 \mathrm{~W}^{0,37}\right)$

Keterangan:

HU : Haungh Unit

$\mathrm{H} \quad$ : Tinggi Albumen (mm)

W : Bobot Telur (g)

b. Perhitungan Indeks Kuning Telur (IKT)

Perhitungan IKT merupakan perbandingan tinggi kuning telur dengan diameter kuning telur. Badan Standar Nasional Indonesia (2008), penjelaskan perhitungan untuk mengetahui Indeks Kuning Telur (IKT) dengan menggunakan rumus berikut:

IKT $=\frac{\text { Tinggi Kuning Telur }}{\text { Diameter Kuning Telur }}$

Data dianalisis secara deskriptif menggunakan rataan dan standar deviasi.

\section{HASIL DAN PEMBAHASAN}

Hasil data Indeks Kuning Telur (IKT), Haugh Unit (HU), bobot telur dan konsumsi pakan pada Itik Magelang ditampilkan pada Tabel 1. Hasil analisis IKT dan HU menunjukkan hasil yang tidak signifikan. Hasil tersebut dipengaruhi oleh jenis pakan yang sama, sehingga tidak ada perbedaan pada nilai IKT dan HU telur dari ketiga jenis itik tersebut. Pakan merupakan komponen penting dalam usaha peternakan. Pakan mempunyai peranan penting dalam proses pembentukan telur. Intestinum tenue akan menyerap nutrien yang dihasilkan dari pakan berupa karbohidrat, protein, lemak, vitamin dan mineral dalam bentuk mikronutrien dan diedarkan keseluruh tubuh melalui aliran darah. Proses metabolisme di dalam sel akan berlangsung secara efisien dan efektif apabila nutrien yang dihasilkan optimal sehingga dapat menjamin ketersediaan bahan baku dala m pros es metabolisme. Hasil metabolisme mikronutrien yang dihasilkan dari pakan tersebut digunakan untuk menunjang pertumbuhan, pemeliharaan, dan produksi telur (Sunarno \& Djaelani, 2011).

Hasil analisis menunjukkan bahwa setiap peternakan memiliki kualitas telur yang berbedabeda. Hasil analisis BT, HU, dan IKT menunjukkan P4 jauh lebih tinggi dibandingkan dengan P1, P2, dan P3, sedangkan untuk tingkat kekentalan telur rata-rata memiliki kekentalan yang sama. Hal tersebut disebabkan karena masa simpan telur yang tidak jauh berbeda yaitu berkisar antara 1-3 hari. Faktor yang dapat mempengaruhi kualitas telur menurut pemaparan dari peternak yaitu pakan dan tempat pemeliharaan. Pakan yang diberikan secara umum berupa campuran dedak, jagung, dan padi, pemberian pakan secara add libitum. Itik dipelihara di area persawahan dan aliran sungai. Dari 
data yang diperoleh pemeliharaan yang dilakukan di area persawahan menunjukkan kualitas telur yang lebih baik dibandingkan di aliran sungai. Di dalam suatu area persawahan, biasanya banyak terdapat sisa biji-bijian hasil panen, keong, dan pakan lainnya yang baik untuk meningkatkan produksi dan kualitas telur itik. Pemeliharaan di aliran sungai, kebanyakan itik hanya memperoleh hewan-hewan kecil seperti keong, sedangkan pakan tambahan lainnya banyak terbawa oleh aliran sungai. Hal tersebut didasari dengan aliran sungai di daerah Sempu termasuk sungai yang memiliki aliran cukup tinggi. Sulistyawan et al. (2018) menyatakan bahwa kualitas telur itik di tingkat peternak dipengaruhi oleh beberapa faktor diantaranya adalah faktor genetik dan lingkungan seperti pakan, umur itik, kebersihan dan suhu lingkungan.

Tabel 1. Hasil analisis Bobot Telur (BT), Haugh Unit (HU), Indeks Kuning Telur (IKT), dan Kekentalan Telur (KT) Itik Magelang

\begin{tabular}{ccccc}
\hline \hline PARAMETER & P1 & P2 & P3 & P4 \\
\hline BT & $64,65 \pm 5.14$ & $65,99 \pm 3,60$ & $60,24 \pm 4,46$ & $66,63 \pm 5,02$ \\
HU & $102,49 \pm 6,21$ & $102,67 \pm 6,15$ & $103,32 \pm 6,82$ & $105,26 \pm 7,93$ \\
IKT & $0,38 \pm 0,12$ & $0,46 \pm 0,13$ & $0,40 \pm 0,11$ & $0,44 \pm 0,06$ \\
KT & Kental & Kental & Kental & Kental \\
\hline
\end{tabular}

Dusun Sempu termasuk daerah yang berada di dataran rendah dan memiliki suhu lingkungan yang relatif normal yaitu berkisar antara $19-24,6^{\circ} \mathrm{C}$. Suhu tersebut masih masih tergolong normal apabila dibandingkan dengan suhu lingkungan yang berada di Daerah Tegal yang dapat mencapai $37^{\circ} \mathrm{C}$. Suhu yang tinggi akan dapat memberikan pengaruh negatif terhadap kualitas telur, sedangkan suhu yang rendah tidak berpengaruh terhadap kualitas telur.

Hasil analisis mengenai BT Itik Magelang menunjukkan P1 64,65 gram, P2 65,99 gram, P3 60,24 gram, dan P4 66,63 gram. Sedangkan hasil dari penelitian Alfiyah et al. (2015) menunjukkan bahwa bobot telur Itik Magelang yaitu 69,53 gram. Bobot telur memiliki keterkaitan dengan nilai HU. Bobot telur yang rendah biasanya disebabkan oleh pemberian pakan yang berlebih, sehingga pakan yang dikonsumsi lebih meningkatkan pertambahan bobot Itik Magelang untuk mempercepat dewasa kelamin. Prasetyo \& Puis (2005) menyampaikan bahwa unggas yang lebih cepat mencapai dewasa kelamin akan menghasilkan telur yang relatif kecil. Bobot telur akan berpengaruh terhadap komponen di dalamnya, sehingga akan memberikan pengaruh pada nilai HU dan IKT. Selain faktor tersebut, kecilnya bobot telur pada penelitian ini juga dipengaruhi oleh nutrien pakan dan jenis unggas terutama gen keturunan. Meskipun di Dusun Sempu memelihara jenis itik yang sama, akan tetapi setiap itik memiliki gen keturunan yang berbeda sesuai dengan induknya. Purdiyanto \& Riyadi (2018) menambahkan bahwa waktu penyimpanan telur juga dapat mempengaruhi berat telur, semakin lama waktu penyimpanan maka semakin besar penurunan berat telur. Penurunan berat telur yang terjadi selama penyimpanan disebabkan oleh penguapan air dan pelepasan gas $\mathrm{CO}_{2}$ dari dalam telur melalui pori-pori kerabang. Penguapan dan pelepadan gas ini terjadi secara terus menerus selama telur disimpan dalam suhu ruang sehingga akan menyebabkan penurunan bobot telur. Nilai susut berat telur selama penyimpanan 2 minggu sebesar $3.63 \pm 1.66 \%$ (Jazil et al., 2013).

Hasil analisis HU telur Itik Magelang menunjukkan kisaran yang tinggi yaitu P1 102,49; P2 102,6; P3 103,3; dan P4 105,26. Data tersebut jauh lebih tinggi dibanding penelitian yang dilakukan oleh Sulistyawan (2018) yang berkisar antara 87,00 dan 83,84. Faktor yang mempengaruhi perbedaan nilai HU adalah jumlah pakan yang dikonsumsi oleh itik. Standar konsumsi pakan itik di Daerah Magelang yaitu 11,72 g/ekor/hari, sedangkan menurut Pengkajian Teknologi Pertanian (2000) konsumsi pakan itik petelur yaitu $150 \mathrm{~g} /$ ekor/hari. Pakan yang diberikan peternak di Dusun Sempu biasanya melebihi standar tersebut karena mereka lebih memfokuskan pada tingkat 
kekenyangan itik. Pemberian pakan yang berlebih belum tentu dapat meningkatkan mutu hasil produksi itik, karena apabila kebutuhan metabolisme sudah tercukupi, sisa pakan akan dibuang menjadi ekskreta. Faktor lain yang mempengaruhi nilai HU adalah bobot telur dan tinggi albumen.

Hasil analisis IKT menunjukkan kisaran antara 0,38-0,44. Hasil analisis tersebut tidak jauh berbeda dengan penelitian yang dilakukan oleh Alfiyah et al. (2015) yang menunjukkan nilai IKT Itik Magelang berada pada kisaran 0,419-0,492. Nilai Indeks Kuning Telur (IKT) normal berkisar antara 0,39-0,45. Faktor yang mempengaruhi tinggi rendahnya nilai IKT yaitu kandungan nutrien dari pakan yang diberikan. Menurut Yuwanta (2004), kandungan protein pada pakan akan memberikan pengaruh terhadap kualitas kekentalan putih telur yang merupakan pembungkus kuning telur. Asam amino (metionin) merupakan nutrien yang dibutuhkan dalam pembentukan struktur albumen dan jala-jala ovomusin, semakin banyak dan kuat jala-jala ovomusin maka albumen akan semakin kental sehingga viskositas albumen juga semakin tinggi .

Tingkat kekentalan telur secara keseluruhan menunjukkan hasil yang sama. Kekentalan telur dapat diketahui saat proses pemecahan telur pada bagian albumen atau putih telur. Albumen mengandung ovomusin yang berperan dalam pengikatan air untuk membentuk gel albumen sehingga albumen bisa kental. Kekentalan albumen ditentukan oleh banyak dan kuatnya ikatan antara jala-jala ovomusin yang dapat meningkatkan viskositas albumen. Semakin tinggi nilai HU maka semakin tinggi ovomusin dan semakin baik kualitas interior telur (Purwati et al., 2015). Hasil penelitian menunjukkan lama penyimpanan telur dalam suhu ruang menyebabkan albumen akan semakin cair dan bobot telur juga akan semakin susut. Selain itu, akan berpengaruh juga terhadap nilai HU. Selama masa penyimpanan suhu sangat mempengaruhi kualitas telur. Menurut Yuwanta (2010), telur yang disimpan pada suhu $25-30^{\circ} \mathrm{C}$ dengan kelembaban relatif $70 \%$ akan menyebabkan telur kehilangan berat 0,8-2 g/minggu/butir. Hal tersebut juga diikuti dengan tingkat kekentalan albumen yang semakin menurun atau semakin cair.

\section{KESIMPULAN}

Dari hasil penelitian tersebut dapat disimpulkan bahwa nilai BT, HU, dan IKT menunjukkan saling berkaitan, sedangkan nilai KT Itik Magelang menunjukkan keseragaman yang baik. Setiap perbedaan hasil analisis dipengaruhi oleh beberapa faktor di antaranya pakan yang diberikan, tempat pemeliharaan, dan lama penyimpanan telur. Semakin lama penyimpanan telur maka kualitas telur akan semakin menurun.

\section{UCAPAN TERIMA KASIH}

Penulis mengucapkan terima kasih pada DRPM yang telah mendanai penelitian dosen pemula 2020 ini.

\section{DAFTAR PUSTAKA}

Ahmadi, F. \& Rahimi, F. (2011). Factor affecting quality and quantity of egg production in laying hen. A. Review. World Applied Science Journal, 12(3): 372-384.

Alfiyah, Y., Praseno, K., \& Mardiati, S. M. (2015). Indeks Kuning Telur (IKT) dan Haugh Unit (HU) telur itik lokal dari beberapa tempat budidaya itik di Jawa. Buletin Anatomi dan Fisiologi. 23(2): $7-15$.

Isomoyowati \& Purwantini, D. (2013). Produksi dan kualitas telur itik lokal Di Daerah Sentra Peternakan Itik. Jurnal Pembangunan Pedesaan 13(1): 11-16.

Jazil N, Hintono, A., \& Mulyani, S. (2013). Penurunan kualitas telur ayam ras dengan intensitas warna coklat kerabang berbeda selama penyimpanan. Jurnal Aplikasi Teknologi Pangan. 2 (1). 
Kurtini, T., Nova, K., \& Septinova, D. (2011). Produksi Ternak Unggas. Bandar Lampung: Universitas Lampung.

Prasetyo, H. \& Pius P. K. (2005). Interaksi antara bangsa itik dan kualitas ransum pada produksi dan kualitas telur itik lokal. Seminar Nasional Teknologi Peternakan dan Veteriner. Bogor: Balai Penelitian Ternak.

Purdiyanto J. \& Riyadi, S. (2018). Pengaruh lama simpan telur itik terhadap penurunan berat, Indeks Kuning Telur (IKT) dan Haugh Unit (HU). MADURANCH: Jurnal Ilmu Peternakan, 3(1), 23-28.

Purnamaningsih, A. (2010). Pengaruh Penambahan Tepung Keong Mas (Pomacea canaliculata Lamarck) dalam Ransum Terhadap Kualitas Telur Itik. Tesis. Solo: Universitas Sebelas Maret.

Purwati, D., Djaelani, M. A., \& Yuniwarti, E. Y. W. (2015). Indeks Kuning Telur (IKT), Haugh Unit (HU) dan Bobot Telur pada berbagai itik lokal di Jawa Tengah. Jurnal Biologi, 4(2), 1-9.

Sulistyawan, I. H., Isomoyowati, \& Indrasanti, D. (2018). Perbedaan produksi dan kualitas telur itik tegal dan itik magelang di tingkat peternak. Prosiding Seminar Teknologi dan Agribisnis Peternakan VI: Pengembangan Sumber Daya Genetik Ternak Lokal Menuju Swasembada Pangan Hewani ASUH, Fakultas Peternakan Universitas Jenderal Soedriman: 205-209.

Sunarno \& Djaelani, A. M. (2011). Analisis produktivitas itik petelur di Kabupaten Semarang berdasarkan indikator nilai konversi pakan, rasio tingkat konsumsi pakan dengan intestinum dan bobot intestinum dengan pertambahan bobot badan. Jurnal Sains dan Matematika, 19(2), 38-42.

Suryana \& Yasin, M. 2013. Studi Tingkah Laku pada Itik Alabio (Anas platyrhynchos Borneo) di Kalimantan Selatan. Disertasi. Kalimantan Selatan: Nasional Inovasi Teknologi Pertanian.

Yuniwarti, E. Y. W. \& Muliani, H. 2014. Status heterofil, limfosit dan rasio H/l berbagai itik lokal di Provinsi Jawa Tengah. Jurnal Ilmu Ternak, 1(5), 22-27.

Yuwanta, T. 2004. Dasar Ternak Unggas. Yogyakarta: Penerbit Kaninus.

Yuwanta, T. 2010. Telur dan Kualitas Telur. Fakultas Peternakan. Yogyakarta: Universitas Gadjah Mada. 